\title{
Hakikat dan Fungsi Negara: Telaah atas Persoalan Kebangsaan di Indonesia
}

\author{
Junaedi \\ Pasca Sarjana Ilmu Hukum Universitas Swadaya Gunungjati Cirebon \\ E-mail : pascajunaedi@gmail.com \\ Agus Dimyati \\ Fakultas Hukum Universitas Swadaya Gunungjati Cirebon \\ E-mail : pascajunaedi@gmail.com
}

\begin{abstract}
The nationality issue arises, one after another, such as the disintegarsi nation, terrorism, KKN until the problem of law enforcement. All this arises when the people no longer have a sense of trust (crisis of trust) in the authorities. If this problem is not handled optimally and continuously to find the root of the problem, the State will not rule out chaos. Therefore, the function of the State must be pursued, carried out and realized to build people's lives based on the 1945 Constitution as its constitutional foundation, and Pancasila as the basis of its morality. Because the State is not private, family, group or any other association. But the State is a shared property that is built and fought together, so the functions of the State must also be built and fought together to build security, order, prosperity and justice in the social space of life as a society, nation and state.
\end{abstract}

Keywords: The nature of the State, the function of the State and nationality

\begin{abstract}
Abstrak
Persoalan kebangsan timbul selih berganti, seperti disintegarsi bangsa, terorisme, KKN samapai kepersoalan penegakkan hukum. Semua ini muncul tatkala rakyat sudah tidak memiliki lagi rasa kepercayaan (krisis kepercayaan) pada penguasa. Bila persoalan ini tanpa ditangani secara optimal dan berkesinambungun untuk mencari akar permasalahannya, maka Negara tidak menutup kemungkinan akan terjadi kekacuan. Oleh karena itu fungsi Negara harus diupayakan, dijalankan dan diwujudkan untuk membangun kehidupan rakyat yang berdasarkan UUD 1945 sebagai landasan konsitusionalnya, dan Pancasila sebagai landasan moralitasnya. Karena Negara bukanlah milik pribadi, keluarga, golongan atau pun perkumpulan lainnya. Tetapi Negara adalah milik bersama yang dibangun dan diperjuangkan secara bersama-sama, maka fungsi Negara pun harus dibangun dan diperjuangkan bersama untuk membangun keamanan, ketertiban, kesejahteraan dan keadilan dalam ruang likup kehidupan bermasyarakat, berbangsa dan bernegara.
\end{abstract}

Kata Kunci : Hakikat Negara, fungsi Negara, dan kebangsaan.

\section{PENDAHULUAN}

Pengkajian tentang hakikat dan fungsi Negara sangatlah menarik untuk diuraikan dalam berbagai dimensi sudut pandang. Negara sebagai organisasi sosial yang tertinggi dalam sebuah komunitas manusia, maka persolan-persolan kebangsaan pun datang silih berganti. Sehingga Negara pun mau tidak mau, suka atau tidak suka harus segera memberikan fungsinya untuk senantisa bisa meredam gejolak-gejolak persoalan yang timbul dalam tatanan masyarakat. Negara dalam konteks ini adalah pemerintah, atau pemangku wewenang yang diamanatkan oleh rakayat untuk mengurusi komplesitas segala dimensi persoalan yang ada dalam tatanan keberlangsungan hidup masyarakat.

Secara hakikat Negara adalah kesatuan sosial yang dibentuk oleh interaksi dimana manusia itu berada. Interaksi yang dianggap terjadi diantara individu-individu yang berasal sari satu Negara telah dinyatakan sebagai suatu unsur sosiologis yang terlepas dari hukum, yang membentuk kesatuan individu dari satu Negara, dan oleh sebab itu membentuk 
Negara sebagai satu realitas sosial. ${ }^{1}$ Berangkat dari pemikiran ini, bahwa Negara sebagai kesatuan individu maka perlu adanya fungsi Negara yang jelas dan terarah untuk mengkafer segala persoalan-persoalan individu yang mengemuka. Dalam konteks sekarang ini, justru fungsi negara ini lebih mengedepankan fungsi individunya sebagai pemimpin negaranya, ketimbang mengedepankan fungsi negaranya sebagai kesatuan individu.

Fungsi Negara dalam konteks Indonesia, sejarah telah membuktikan, ketika bangsa ini dibawa kepemimpinan Orde Lama Soekarno, maka arah dan fungsi Negara hanya mengedepankan ideologi Soekarno dengan ide-ide politik kebangsaannya. Kempemimpinan Orde Baru Soeharto, fungsi Negara lebih cenderung mengedapankan aspek pembangunan dengan mengusung ideologi Pancasila sebagai ideologi pembangunannya, walaupun realisasinya tidak berjalan dengan baik. Dan sekarang, dibawah Orde Reformasi, fungsi Negara mengusung ide-ide perubahan-reformasi total dalam segala aspek kehidupan, namun disayangkan ide-ide reformasi masih berjalan ditempat, hanya sebatas wacana pablik, realisasinya masih banyak persoalan kebangsaan yang belum terselesaikan dengan baik. Dengan demikian, hakikat dan fungsi Negara dalam konteks Indonesia perlu adanya ketegasan dari pemangku kedaulatan rakyat yang harus dijabarkan dalam sebuah aturan hukum yang tegas, jelas dan tearah serta berpihak untuk kepentingan semua komponen bangsa. Setelah itu, haruslah pula diwujudkan dalam realitanya sebagai fakta-fakta sosial bahwa fungsi Negara yang hakikatnya adalah untuk membangun kehidupan masyarakat yang bertumpu pada nilai-nilai kemanusian yang adil dan beradab untuk mewujudkan prinsip keadilan sosial bagi seluruh rakyat Indonesia. oleh karena itu hakikat dan fungsi Negara harus dituangkan dalam konstitusi Negara. Berdasarkan uraian diatas maka penulis merumuskan permasasalahan yaitu Bagimana Hakikat dan Fungsi Negara: Telaah atas Persoalan Kebangsaan di Indonesia?

\section{METODE PENELITIAN}

Metode penelitian yang digunakan oleh penulis adalah yuridis normatif, dengan alat pengumpul data melalui studi kepustakaan yaitu studi dokumentasi peraturan perundangundangan serta artikel-artikel yang terkait dengan penelitian ini

\section{HASIL DAN PEMBAHASAN}

\section{A. Definisi Negara dan Fungsi Negara}

Pengertian Negara yang diutarakan para ahli ketatanegaraan sangat aneka ragam, dengan sudut pandang yang berbeda. Ahli politik sudah tentu mendefiniskan Negara dari sudut pandang politik, ahli hukum juga menguraikan arti Negara dalam koteks hukum, begitu juga ahli sosiologi, mendefinisikan Negara dalam kajian-kajian sosiologi. Namun semua ahli sepakat, bahwa Negara itu harus ada, apa pun bentuknya, karena adanya masyarakat maka adanya Negara pun diperlukan. Negara sebagai kesatuan individu-idividu yang terorganisir dan mendiami sebuah wilayah serta berdaulat. Pada dasarnya keberadaan Negara diperlukan mutlak dalam sebuah kesatuan individu-individu untuk menjaga dan melindunggi keberlangsungan hidup masyarakat.

\footnotetext{
${ }^{1}$ Kelsen, Hans, 2006, General Theory of Law and Satate, New York: Rusesel and Russel, 1971. Terjemahan Indobesia, Hans Kelsen, Teori Umum Tentang Hukum Dan Negara, Bandung: Nuansa,hlm.264.
} 
Menurut Hans Kelsen dalam bukunya General Theory of Law and Satate, mengungkapkan, bahwa istilah Negara kadang-kadang digunakan dalam pengertian yang sangat luas untuk menyebut 'masyarakat', atau bentuk khusus dari masyarakat. Tetapi istilah itupun sangat sering digunakan dalam pengertian yang sangat sempit untuk menyebut suatu organ khusus masyarkat - misalnya pemerintah, atau para subyek pemerintah, 'bangsa', atau wilayah yang mereka diami. ${ }^{2}$ Pengertian Negara bagi Hans Kelsen selalu mengkaitankan dengan aspek hukum, keadannya tanpak lebih sederhana jika Negara dibahas dari teori hukum ilmu hukum murni. Bagi Kelsen, Negara hanya dipandang sebagai fenoma hukum, sebagai badan hukum, yakni korporasi. Sehingga muncul persoalan, dimana letak perbedaan Negara dengan korporasi-korporasi lainnya. Hans Kelsen, tidak memberikan penjelasan yang konkrit, antara apa yang dimaksud dengan Negara dan korporasi. Namun perbedaanya mesti terletak pada tatanan norma yang membetuk korporasi Negara.

Sedangkan pengertian Negara berdasarkan Kamus Besar Bahasa Indonesia; Negara adalah; pertama, organisasi dalam suatu wilayah yang mempunyai kekuasaan tertinggi yang sah dan ditaati oleh rakyat; dan kedua; kelompok sosial yang menduduki wilayah atau daerah tertentu yang diorganisasi dibawah lembaga politik dan pemerintah yang efektif, mempuyai kesatuan politik, berdaulat sehingga berhak menentukan tujuan nasionalnya. Aristoteles pemikir Yunani Kuno, mengartikan bahwa Negara adalah suatu kekuasaan masyarakat (persekutuan dari pada keluarga, desa/kampung) yang bertujuan untuk mencapai kebaikan yang tertinggi bagi umat manusia. ${ }^{3}$

Sementara itu menurut Max Weber, Negara adalah suatu masyarakat yang mempunyai monopoli dalam penggunaan kekerasaan fisik secarah sah dalam sesuatu wilayah. Pandangan Max Weber dalam mengartikan Negara, cenderung memberikan sifat Negara yakni memaksa untuk menggunakan kekerasan dalam mengatur tatanan masyarakatnya, pemikiran ini dilihat dari sudut pandang sosiologi. Menggunakan kekerasan bagi Negara sebagai sifatnya dilegalkan dalam pandangan Max Weber, bahkan diharuskan apabila Negara dalam keadaan darurat, atau adanya pemberontakan fisik dari rakyat maupun adanya serangan dari luar. Sedang menurut Robert M. Maclver, menyatakan bahwa Negara adalah asosiasi yang menyelenggarakan penertiban di dalam suatu masyarakat dalam suatu wilayah dengan berdasarkan sistem hukum yang diselenggarakan oleh suatu pemerintah yang untuk maksud tersebut diberi kekuasaan memaksa. ${ }^{4}$ Kajian Negara dalam pandangan Maclver ini lebih mengedapkan aspek hukumnya, bahwa kekuasaan Negara memiliki hak untuk membuat sebuah aturan hukum, dimana aturan hukum itu diselenggaran untuk penertiban akan keberlangsungan hidup masyarakatnya.

C. F. Strong dalam bukunya yang berjudul Modern Political Constitutions: An Intrudiction to the Comparative Study of Their History and Exisiting Form, ia mengungkapkan bahwa hakikat suatu Negara, yang membuatnya berbeda dengan semua bentuk perkumpulan yang lain adalah kepatuhan-kepatuhan anggotanya terhadap hukum, Negara sebagai suatu masyarakat teretorial dibagi menjadi yang memerintah dan yang

\footnotetext{
${ }^{2}$ Ibid. hlm.261

${ }^{3}$ Diponalo, G.S, 1975, Ilmu Negara, Jilid I, Jakarta: Balai Pustaka,hlm.23

${ }^{4}$ Maclver, Robert. M, 1955, The Modern State, London: Oxford University Press, hlm.22
} 
diperintah. ${ }^{5}$ Strong, mendefinsikan Negara dalam upaya mengungkapan akan karaktersitik Negara modern, dimana kehidupan Negara yang lebih komplek dan kepatuhan hukum masyarakat sangat kuat, bila dibandingkan dengan anggota perkumpulan selain Negara, sehingga menimbulkan keselaran hubungan antara yang memerintah dan diperintah berjalan begitu sinergis. Pengertian ini sejalan dengan apa yang diungkapan oleh Miriam Budiardjo, yang menyatakan bahwa Negara adalah suatu daerah teretorial yang rakyatnya diperintah (Governed) oleh sejumlah pejabat dan yang berhasil menuntut dari warga negaranya ketaatan pada peraturan perundang-undangan melalui penguasaan (kontrol) monopolitis dari kekuasaan yang sah. ${ }^{6}$

Negara bukanlah organisasi yang dapat dibuat oleh manusia untuk kepentingan diri sendiri, tetapi negara adalah suatu gejala sosial dan politik yang memiliki kekuasaan tertinggi untuk mengatur warga negaranya yang mendiami sebuah wilayah. Menurut H.J.W. Hetherington bahwa Negara adalah sebuah istitusi atau seperangkat institusi yang menyatukan penduduknya dalam suatu wilayah teretorial yang ditandai secara jelas dibawah otoritas tunggal untuk menjamin tercapainya tujuan dasar dan kondisi kehidupan bersama. ${ }^{7}$ Oleh karena itu, Negara memiliki kekusaan/otoritas, maka Negara menetapkan mekanisme dan batasan sampai dimana kekusaan itu dapat digunakan dalam kehidupan bersama. Sehingga Negara dapat mengintegrasikan dan membimbing kegitan-kegiatan sosial dari penduduknya kearah tujuan bersama. Dalam rangka ini dapatlah dikatakan bahwa Negara mempunyai dua fungsi yakni : (1) Mengatur dan mengendalikan gejala-gejala kekuasaan yang a-sosial, yakni yang bertentagan satu sama lain, supaya tidak menjadi antagonisme yang membahayakan; dan (2) Menggorganisir dan mengintegrasikan kegiatan manusia dan golongan-golongan ke arah tercapainya tujuan-tujuan dari masyarakat seluruhnya. Negara menentukan bagaimana kegiatan asosiasi-asosiasi kemasyarakatan disesuaikan satu sama lain dan diarahkan kepada tujuan nasional. ${ }^{8}$

Sementara menurut Franz Magnis Suseno, semua fungsi Negara dapat dikembalikan pada satu funsi formal yakni Negara mempermaklumkan, menerapkan dan menjamin, seperlunya secara memaksa, keberlakuan aturan-aturan kelakuan bagi seluruh masyarakat. ${ }^{9}$ Sedangkan menurut John Locke, bahwa fungsi Negara bisa dilihat dari ketiga hal : (1) fungsi legislasi yakni fungsi membuat undang-undang dan peraturan; (2) fungsi eksekutif, fungsi untuk melaksanakan peraturan, dan (3) fungsi federative yaitu fungsi untuk mengurusi urusan luar negeri dan urusan perang dan damai. Teori John Locke ini kemudian disempurnakan oleh Montesqueiu, dengan membagi fungsi Negara menjadi tiga bagian; (1) fungsi legislatif, fungsi untuk membuat undang-undang; (2) fungsi eksekutif, fungsi untuk melaksanakan undang-undang; dan (3) fungsi yudikatif, fungsi untuk mengawasi agar semua aturan untuk ditaati (fungsi mengadili). ${ }^{10}$

\footnotetext{
${ }^{5}$ Strong, C.F, 2004, Modern Political Constitutions: An Intrudiction to the Comparative Study of Their History and Exisiting Form, London: The English Book Society and Sidgwick \& Jackson Limetid, 1966. Terjemahan Indonesia, C.F. Strong, Konstitusi-Konstitusi Politik Modern (Kajian Tentang SEjarah \& Bentuk-Bentuk Konsitusi Dunia), Bandung: Nusamedia, hlm.6

${ }^{6}$ Budiardjo, Miriam, 200o, Dasar - Dasar Ilmu Politik, Jakarta: PT. Gramedia,hlm.40

${ }^{7}$ Ibid.Strong,hlm.7

${ }^{8}$ Ibid.Marim Budiarjo,hlm.38

${ }^{9}$ Suseno, Franz Magnis, 2001, Etika Politik (Prinsip-Prinsip Moral Kenegaraan Modern), Jakarta: PT. Gramedia, hlm.170

${ }^{10}$ Soetomo, 1986, Ilmu Negara, Surabaya: Usaha Nasional,hl.37
} 
Pemikiran Montesqueiu tentang fungsi Negara diatas dikenal dengan teori trias politika. Pemikiran ini hampir dianut oleh Negara-negara modern pada era sekarang ini, yang membagi kekuasaan Negara berdasarkan tiga lembaga Negara yakni eksekutif, legislative dan yudikatif diamana ketiga lembaga Negara itu memiliki fungsi dan peran yang berbeda dalam mengelolah kekusaan Negara, namun memiliki tujuan yang sama untuk membangun bangsa dan rakyatnya kearah yang lebih baik. Miriam Budiardjo dalam bukunya dasar-dasar ilmu politik, menguraikan akan fungsi Negara secara umum yakni (1) melaksanakan penertiban (law and order); (2) mengusahakan kesejahteraan dan kemakmuran rakyat; (3) pertahanan; dan (4) menegakan keadilan. Sedangkan menurut Charles E. Merriam menyebutkan ada lima fungsi Negara yang harus mutlak ada, yakni (1) keamanan ekstren; (2) ketertiban intern; (3) keadilan; (4) kesejahteraan umum; dan (5) kebebasan. ${ }^{11}$

Membicarakan fungsi Negara sama halanya dengan memperoalkan tentang bagaimana fungsi pemerintahan yang seharusnya dijalakan sesuai dengan apa yang diamanatkan dalam konstitusi. Sehingga jalannya fungsi Negara yakni fungsi pemerintahan dalam mengelolah tatanan negaranya, harus didasarkan atas, (1) Wetgeving, penentuan aturan-aturan hukum yang mengikat; (2) Rechtspraak, penentuan hukum atas kejadiankejadian yang nyata pada perselisihan dan penjatuhan hukuman pelanggaran-pelanggaran umum yang mengikat; (3) Uitvoering, yaitu tentang pelaksanaan peradilan; dan (4) Bestuur, yaitu tiap-tiap tindakan pemerintah yang tidak termasuk dalam bagian peraturan-peraturan atau. Dengan demikian, fungsi Negara harus dijabarkan dalam sebuah aturan hukum yang jelas, tegas dan terarah untuk diwujudkan, direalisasikan, dan buktikan pada realitas kehidupan bermasyarakat, berbangsa dan bernegara.

\section{B. Fungsi Negara dalam Konteks Negara Indonesia}

Menurut Soekarno, presiden pertama Republik Indonesia, kata "Indonesia" berasal dari etnologi Jerman bernama Jordan yang belajar di Hollad. Spesialis studinya adalah rangkaian kepulauan Indonesia. Karena dekatnya kepulauan ini dengan India, dia menyebutnya 'kepulauan Hindia'. Nesos berasal dari bahasa Yunani untuk kata pulau, kemudian kata ini menjadi Indusnesos - yang pada akhirnya menjadi Indonesia. ${ }^{12}$ Indonesia berarti Negara kepuluan, yang terdiri dari 13.677 pulau, 6.044 sudah punya nama dan 7.623 yang belum punya nama, sekitar 70\% atau 391 pulau yang dihuni oleh penduduk. Mungkin Indonesia adalah satu-satunya Negara di dunia yang paling majemuk dari segi kultural dan etnisnya. Menurut Hildred Geertz dalam bukunya Indonesia Cultures and Communitties, yang menggambarkan akan keanekaragaman masyarakat Indonesia: "Terdapat lebih dari 300 kelompok etnis di Indonesia, masing-masing mempunyai identitas kultural sendiri, dan lebih dari 250 jenis bahasa dipakai, hampir semua agama dunia diwakili selain agama asli yang banyak sekali jumlahnya". ${ }^{13}$

\footnotetext{
${ }^{11}$ Ibid.Mariam Budiarjo,hlm.46

${ }^{12}$ Soekarno, 1965, Seokarno An Autobiography as Told to Cindy Adams, New York: The Bobbs-Mariil Company in, hlm.63

${ }^{13}$ McVey, R.T, 1963, Indonesia, New Haven: Yale University Press, hlm.24
} 
Para pendiri bangsa ini, untuk menggambarakan akan pluralitas masyarakat dan budaya Indonesia, maka pada tahun 1945 telah mengumandangkan motto nasional yakni Bhineka Tungal Ika, motto ini diambil dari formulasi Empu Tantular, seorang pemikir zaman kerajaan Hindu Majapahit. Dengan kemajemukan itu maka persoalan kebangsaan yang sering muncul kepermukaan adalah persolan disitegrasi bangsa, gerakan separatis yang ingin melepaskan dari NKRI. Sejarah bangsa ini telah membuktikan, semenjak Indonesia meredeka lepas dari dominasi penjajahan bangsa asing, gerakan-gerakan separatis muncul kepermukaan, ada yang mengatasnamakan agama, seperti Pembrontakan DI/TII Kartosuwiryo pada masa Orde Lama, Gerakan Aceh Merdeka (GAM) di masa Orde Baru, Pemberontakan atas nama ideologi kebangsaan seperti peristiwa G/30/S/PKI dan gerakan separatis lainnya disejumlah daerah. Imbas dari rentetan gerakan separatis ini, di masa kepemimpinan BJ Habibi, Timor Leste melepaskan diri dari pangkuan NKRI. Sekarng pun akar persoalan di Papua belum terselesaikan dengan baik, sering muncul radikalisme untuk melepaskan dari NKRI.

Memahami persoalan kembangsaan khusunya dalam konteks disintegrasi bangsa, persoalan ini muncul kepermukaan tatkalah kurangnya perhatian Negara yakni pemerintah dalam mendistribusikan nilai-nilai keadilan sosial bagi seluruh rakyat Indonesia. Pembangunan yang kurang merata di setiap daerah, baik pembangunan Sumber Daya Manusianya, maupun pembangunan infrastruktur dan suprastrukturnya. Intinya persoalan disintegarsi bangsa mengemuka disebabkan kurangnya kepekaan sosial bagi para pemangku kekuasaan, mereka melupakan akan potensi daerah yang sewaktu-waktu bisa memunculkan radikalisme yang bisa mengancam keutuhan NKRI. Dalam konteks yang demikian ini, bahwa fungsi Negara harus dioptimalkan dan dijalankan sesuai dengan apa yang diharapkan oleh semua komponen bangsa ini. Fungsi Negara sudah tentu harus dijalankan oleh mereka yang diusung oleh rakyat yakni pemimpin dan diarahkan untuk kemajuan dan kesejahteraan rakyat yang dipimpinnya ${ }^{14}$.

Persoalan kebangsaan lainnya, adalah Korupsi, Kolusi dan Nepotisme (KKN) ini adalah persoalan yang sangat sulit untuk dituntaskan. KKN sudah mendarah daging, KKN sudah membudaya yang diwariskan dari genrasi-ke genarasi. KKN ibarat sebuah virus yang mematikan, menggerogoti kekebalan tubuh bangsa ini. Lambat-laun KKN tidak segara dituntaskan dengan baik, tidak menutup kemungkinan bangsa ini akan hancur, luluhlantah, bisa jadi Indonesia tinggal sebuah nama saja. KKN tidak lepas dari sistematik lingkaran kekuasan, para pemangku amanah rakyat tidak jarang yang melakukan KKN. Padahal tindakan KKN sangat merugikan rakyat dan bangsa ini. Satu hal yang perlu diperahtikan adalah kesadaran moral, dimana kesadaran moral sudah mulai dilupakan, dan lebih mengusung pada budaya materalisme dan hedonisme sebagai orentasi hidupnya.

Persoalan gerakan radikalisme yang mengatasnakaman agama yakni terorisme, masih menjadi persoalan kebangsaan yang belum terselesaikan, sewaktu-waktu datang menyebarkan teror bom bunuh diri di tempat-tempat umum/peribadatan hingga memakan korban jiwa yang tak bersalah. Inilah persoalan kebangsaan yang masih belum terpecahkan akan akar permasalahannya, jika salah dalam penilaian akan menyebabkan konflik

\footnotetext{
${ }^{14}$ Deby Deviyanti, Haris Budiman dan Bias Lintang Dialog. Implementasi Putusan Mahkamah Konstitusi Nomor 46/PUU-VIII/2010 tentang Anak di Luar Nikah (Studi Kasus di Kabupaten Kuningan). Logika : Journal of Multidisciplinary Studies, ISSN 2085-9970. Vol. o9 Nomor o1 Juni 2018. 1-10.
} 
keagamaan. Terorisme tidak dibenarkan dalam ajaran agama manapun, karena terorisme bertolak belakang dengan nilai-nilai kemanusiaan (HAM).

Sementara itu persoalan aspek penegakan hukum atau supremasi hukum masih menjadi persoalan kebangsaan, dimana rakyat selama ini belum sepenuhnya merasakan apa yang namanya keadilan sosial bagi seluruh rakyat Indonesia. Sejatinya penegakkan hukum harus melindungi, mengayomi dan mensejahterakan bagi kelangsungan hidup manusia. Menurut filosof Yunani Socrates (469 - 399 SM) ketika mencari dasar-dasar kedalian hukum yang sejati, ia mengutarakan bahwa, "ditap-tiap hati kecil manusia itu ada rasa keadilan yang sejati ada terdengar detik kesucian, karena tiap-tiap orang itu ialah sebagaian dari Nur Tuhan yang Maha Adil. Detik kesucian itu dapat tertutup oleh kabut kemilikan, keserakahan dan lain-lain tetapi tetap ada dan tak dapat dihilangkan". ${ }^{15}$

Indonesia adalah Negara yang berdasarkan atas hukum, begitulah UUD 1945 menyebutkan, artinya hukum menjadi benteng terakhir untuk menatata kehidupan masyarakat Indonesia, guna membangun manusia Indonesia seutuhnya baik dalam kehidupan bermasyarakat, berbangsa dan bernegara. Tercapai tidaknya tujuan bernegara berujung pada bagaimana lembaga-lembaga negara tersebut melaksanakan tugas dan wewenang konstitusionalnya serta pilihan penyelenggaraan negara dalam bentuk relasi antar lembaga negara. ${ }^{16}$ Dengan demikian penegakkan hukum harus ditegakkan, Negara harus mengkokohkan sistem hukum, masyarakat harus memiliki kesadaran hukum. Oleh karena itu perlu kisenergisan dalam penegakkan hukum, antara pemerintah, aparat hukum dan rakyat sebagai upaya untuk mewujudkan Negara hukum Indonesia.

Memahami persoalan kebangsan yang begitu kompleks, muali dari persoalan disintegarsi bangsa, terorisme, KKN sampai kepersoalan penegakan hukum. Dengan ini fungsi Negara harus dioptimalkan, diwujudkan, dijalankan dan diaktualisasikan sesuai dengan aturan hukum yang ada yakni UUD Tahun 1945 sebagai landasan konstitusionalnya dan Pancasila sebagai landasan moralitasnya. Ada pun fungsi Negara yang harus diperhatian, dioptimalkan dan diwujudkan dalam mengatasi berbagai persoalan kebangsaan adalah sebagai berikut :

a) Fungsi pertahanan, artinya Negara harus mempunyai kemampuan menanggulangi timbulnya serangan dan ancaman, baik dari dalam maupun dari luar dengan cara membentuk alat Negara yang tangguh demi kokoh dan tegaknya Negara.

b) Fungsi keamanan dan ketertiban, dalam arti Negara harus mampu menciptakan suasanan yang aman, damai, tentram dan harmonis bagi kelangsungan hidup warga negaranya.

c) Fungsi kesejahteraan, artinya Negara harus benar-benar mengadakan pembangunan yang merata dalam segala dimensi kehidupan, demi mewjudkan pembangunan yang adil dan makmur berdasarkan nilai-nilai keadilan sosial bagi seluruh rakyat Indonesia.

d) Fungsi keadilan, Negara dalam konteks ini diupayakan harus bisa menegakan keadilan dengan menyelengarakan sistem peradilan dan penegakkan hukum yang bebas intervensi dari kekuasaan dengan segala bentuknya, untuk menjamin dan melindungi warga negaranya.

\footnotetext{
${ }^{15}$ Lubis, M. Solly, 1981, Ilmu Negara, Bandung: Penerbit Alumni,hlm.21

${ }^{16}$ Abustan, Relasi Lembaga Negara Dalam Perspektif Undang Undang Dasar Negara Republik Indonesia 1945, Jurnal Unifikasi, Issn 2354-5976, E-Issn 2580-7382 Vol. o4 Nomor o2 Juli 2017
} 
Negara bukan sekedar kumpulan keluarga belaka atau suatu persatuan organisasi profesi, atau penengah diantara kepentingan-kepentingan yang saling bertentangan antara perkumpulan suka rela yang diizinkan keberadaannya oleh Negara. Dalam suatu komunitas politik yang diorganisir secara tepat, kebeardaan Negara adalah untuk masyarakat dan bukan masyarakat yang ada untuk Negara ${ }^{17}$. Akan tetapi, betapapun majunya rakyat secara sosial, masyarakat yang menyusunnya - terdiri dari keluarga, klub, perkumpulan agama, serikat dagang dan lain-lain - tidak menjamin dapat menyelenggarakan urusannya sendiri tanpa adanya kekuasaan arbitrase tertinggi yakni Negara. Oleh karena itu, fungsi Negara harus didasarkan atas kepentingan bersama untuk kemajuan bersama, bukan fungsi Negara didasarkan atas kepentingan penguasa semata, sehingga pada akhirnya memunculkan persoalan kebangsaan sebagai rasa kurang percayanya rakayat pada penguasa.

\section{SIMPULAN}

Menurut Reousseau, bahwa fungsi utama sebuah Negara yang paling menonjol adalah fungsi melaksanakan pemerintahan atau melaksanakan undang-undang. Fungsi Negara untuk melaksanakan pemerintahan atau undang-undang ini, dalam praktiknya, tidak mungkin dilakukan oleh rakyat secara langsung, namun rakyat hanya sebatas pemegang kedaulatan. Melalui badan perwakilan itulah, rakyat mewakilkan akan hakhaknya, dimana persoalan kebangsaan diserahkan sepenuhnya secara konstitusional oleh badan-badan tinggi Negara. Badan-bandan tinggi Negara itulah para pemegang kekuasaan untuk mengelolah dan metata berbagai dimensi kehidupan rakyat.

Berangkat dari pemikiran tersebut, maka lahirlah fungsi Negara untuk mengaktualisasikan akan keingian-keingian rakyat sebagai tujuan Negara yang harus diwujudkan dalam realitas kehidupan. Tanpa dasar pertimbangan-pertimbangan akan keinginan rakyat bersama untuk hidup damai, tentram, harmonis dan sejahtera, maka fungsi Negara tidak akan berjalan dengan baik. Sehingga persoalan-persoalan kebangsaan muncul kepermukaan selih berganti, yang inti dari semua ini adalah bahwa kekusaan Negara tidak boleh ditumpangi akan mental-mental aroganisme, hedonisme, dan materialisme tatkalah fungsi Negara dijalankan.

\section{SARAN}

Negara bukanlah milik pribadi, keluarga, golongan atau pun perkumpulan lainnya. Tetapi Negara adalah milik bersama yang dibangun dan diperjuangkan secara bersamasama, maka fungsi Negara pun harus dibangun dan diperjuangkan bersama untuk membangun keamanan, ketertiban, kesejahteraan dan keadilan dalam ruang likup kehidupan bermasyarakat, berbangsa dan bernegara.

\section{DAFTAR PUSTAKA}

Abustan, Relasi Lembaga Negara Dalam Perspektif Undang Undang Dasar Negara Republik Indonesia 1945, Jurnal Unifikasi, Issn 2354-5976, E-Issn 2580-7382 Vol. 04 Nomor 02 Juli 2017

Budiardjo, Miriam, Dasar - Dasar Ilmu Politik, Jakarta: PT. Gramedia, 2000.

\footnotetext{
${ }^{17}$ Dede Yusuf, Asas Kepentingan Umum dalam Pengadaan Tanah untuk Kepentingan Negara, Logika : Journal of Multidisciplinary Studies, p-ISSN 2085-9970. e-ISSN 2715-4505 Vol. 10 Nomor 02 Desember 2019. 100-105
} 
Deby Deviyanti, Haris Budiman dan Bias Lintang Dialog. Implementasi Putusan Mahkamah Konstitusi Nomor 46/PUU-VIII/2010 tentang Anak di Luar Nikah (Studi Kasus di Kabupaten Kuningan). Logika : Journal of Multidisciplinary Studies, ISSN 20859970. Vol. o9 Nomor o1 Juni 2018. 1-10.

Dede Yusuf, Asas Kepentingan Umum dalam Pengadaan Tanah untuk Kepentingan Negara, Logika : Journal of Multidisciplinary Studies, p-ISSN 2085-9970. e-ISSN 2715-4505 Vol. 10 Nomor 02 Desember 2019. 100-105

Diponalo, G.S, Ilmu Negara, Jilid I, Jakarta: Balai Pustaka, 1975.

Kelsen, Hans, General Theory of Law and Satate, New York: Rusesel and Russel, 1971. Terjemahan Indobesia, Hans Kelsen, Teori Umum Tentang Hukum Dan Negara, Bandung: Nuansa, 2006.

Lubis, M. Solly, Ilmu Negara, Bandung: Penerbit Alumni, 1981.

Maclver, Robert. M, The Modern State, London: Oxford University Press, 1955.

McVey, R.T, Indonesia, New Haven: Yale University Press, 1963.

Soekarno, Seokarno An Autobiography as Told to Cindy Adams, New York: The Bobbs-Mariil Company in, 1965.

Soetomo, Ilmu Negara, Surabaya: Usaha Nasional, 1986.

Strong, C.F, Modern Political Constitutions: An Intrudiction to the Comparative Study of Their History and Exisiting Form, London: The English Book Society and Sidgwick \& Jackson Limetid, 1966. Terjemahan Indonesia, C.F. Strong, Konstitusi-Konstitusi Politik Modern (Kajian Tentang SEjarah \& Bentuk-Bentuk Konsitusi Dunia), Bandung: Nusamedia, 2004.

Suseno, Franz Magnis, Etika Politik (Prinsip-Prinsip Moral Kenegaraan Modern), Jakarta: PT. Gramedia, 2001. 